\title{
FOR STILL POSSIBLE CITIES: A POLITICS OF FAILURE FOR THE POLITICALLY DEPRESSED
}

Natalie Osborne

Lecturer

School of Environment and Science

Griffith University

Brisbane, QLD, 4111

\section{Abstract}

We lost. Now what?

\section{"[the revolution] you desire is actually an obstacle to your flourishing"1}

Let us sit with the idea, for a moment, that we have lost.

For every \#metoo, there is a chorus of anxious neck-tie-clutching about how things have gone too far, and the deeply misogynistic and bloodied claims of 'incels' are receiving mainstream thinkpiece consideration. Aboriginal and Torres Strait Islander Peoples are disproportionately criminalised (Australian Law Reform Commission 2017), and significant and devastating health gaps remain (Holland 2018). The Uluru Statement From the Heart and the Makarrata Commission it proposed offered a pathway to more substantive forms of justice (Delegates at the Referendum Convention at Uluru 2017), but was rejected by the Turnbull Government (Gordon 2017). Indeed, we live in

\footnotetext{
${ }^{1}$ From Lauren Berlant (2011, p1): "A relation of cruel optimism exists when something you desire is actually an obstacle to your flourishing. It might involve food, or a kind of love; it might be a fantasy of the good life, or a political project" (emphasis added).
} 
a time when papers justifying, even promoting, colonialism are published and defended (Sultana 2018). The reinvigorated alt-right is reinforcing white supremacist heteropatriarchal capitalism. Palestine. Manus Island. Let us not discuss the White House, or the eager adoption of Australianstyle border enforcement. Our cities are increasingly inequitable and precarious places. Climate change is here. The Great Barrier Reef is dying. We've already lost untold, uncounted, species to extinctions, and for many more the "slow unraveling" (Van Dooren 2014, p.12) is underway. It's time for some of us, at least, to be "thinking systematically about worst-case scenarios" (Head 2016, p.3).

There have been moments in the West where we - feminists, anti-capitalists, anti-racists, queer activists, environmentalists, urban activist-scholars for the Just City - thought that perhaps things were turning towards us. There was a moment when the revolution we yearned for was possible, even imminent (and of course, battles were won, with material implications). I took comfort in the 'late' of 'late capitalism', invoking as it does both an imminent demise and a post-demise state. As the fissures and contradictions of neoliberalism rendered themselves more obvious, I took heart, thinking (to paraphrase Arundhati Roy) another world - our world - was on her way. But capitalism's self-destructive nature is not necessarily our victory. In 2015, Isabelle Stengers wrote:

“There isn't the slightest guarantee that we will be able to overcome the hold that capitalism has over us... Nor do we know how... we might live in the ruins that it will leave us: the window of opportunity in which, on paper, the measures to take were reasonably clear, is in the process of closing" (Stengers 2015, p.10).

Perhaps the window Stengers spoke of has now closed; that we are past the point at which we could Agenda21/ Inconvenient Truth/ Hope-and-Change/ UNDRIP/ UDHR/ KyotoProtocol/ Copenhagen-Accord/ Lean-In/ global-workers'-revolution our way out of this mess. Whole ways of living and dying have passed and are passing from this Earth, we have lost futures, and the basics of a good life are still denied to most. Anna Tsing (2015, p.2) argues that we are 
now all precarious, "confront[ing] the condition of trouble without end", and the grand, global feminist ecological revolution - the end of our trouble - is perhaps an example of what Berlant (2011) calls a cruel optimism. My every moment is suffused with a panicky inadequacy - so much to do, none of it enough. Every action available to me feels laughably pathetic, tilting at coal-fired power stations. The fight to save The World is a breathless, never-ending state of catastrophe - a flailing, cacophonous emergency.

Perhaps release may come from considering that we are not in the midst of a desperate, heated, chaotic battle to save The World. In fact, we lost that battle, lost that future, lost that world.

We. Have. Lost.

Take a breath.

Now what?

\section{"Depressed? It might be political"2}

I write this for politically depressed urban activists, feminist-scholar-activists, environmentalists, anti-capitalists, anarchists, Marxists, decolonial, anti-racist and/or queer activists and organisers against white hetereosexist hegemony, for those experiencing a bleak ennui, for those whose twisted panic contorts toward paralysis, for those who feel like we are in the darkest timeline. ${ }^{3}$ For those who are hopeful, optimistic, energised - thank you. I appreciate, admire, need you sometimes I am even one of you. I do not want to convince you that you've lost. Scorn this admission of (my) defeat and do not read on. Tuck this paper away in case you need it sometime (I hope you don't). I wish to talk with those already feeling political depression - i.e. "the sense that customary forms of political response, including direct action and critical analysis, are no

\footnotetext{
2 Slogan drawn from the Public Feelings feel tank - see Berlant (2012).

3 The Darkest Timeline is a meme based on a kind of multirealism, emerging out of the television show Community. From Know Your Meme (2017): “The Darkest Timeline is a reference to the multi-verse theory which hypothesizes that there are multiple universes outside of our own in which all things are possible, and that we live in the worst possible of these universes."
} 
longer working either to change the world or to make us feel better" (Cvetkovich 2012, p.1) - with me. -While I hope this state is not perpetual, it feels important to theorise from here, to see this as part of the work too.

For those still with me: I worry sometimes our politics of hope lets us down. Sometimes hope flags or fails, or does not meet us where we are. In grief, loss, and trauma, we cannot always talk ourselves back into hope or optimism. Sometimes hope is entirely pointless, a form of denial (Head 2016), and optimism depressogenic and cruel (Berlant 2011). Further, some of these negative feelings must be, should be felt - indeed more than they currently are. There are still many lives human and more-than-human - that are ungrieved, ungrievable (Butler 2004; Butler 2009; Van Dooren 2014), and if we are to take seriously our obligations to each other we must recognise and grieve our failures to do so.

Sisters, comrades, friends, in the face of our losses, part of our 'now what' is a politics of failure and depression, which reflects and helps us understand our affective experiences in late capitalism, that lets us grieve loss, but does not abandon us to it. Ann Cvetkovich (2012, p.2) writes:

"The concept of political depression is not...meant to be wholly depressing...The goal is to depathologize negative feelings so that they can be seen as a possible resource for political action rather than as its antithesis...but these feelings, moods, and sensibilities become sites of publicity and community formation."

Our negative feelings are always already political, rich with possibilities as well as impossibilities, and loss is not a fixed state. How can a politics of failure and a politics of depression help us form communities? How can we think-with, and act from, this place - from the battlefield where hope for a global ecosocialist, ecofeminist revolution died, where we stand knee deep in ashes and bones? It is possible: depression is not the antithesis of action (Cvetkovich 2012), and we can salvage lifeways from toxic ruins (Davis 2015; Stengers 2015; Tsing 2015; Tsing, Swanson, Gan \& Bubandt 2017). 
I dig ashes, blood, bone, and shit into my garden bed. They help things grow.

\section{"The queer art of failure...quietly loses, and in losing it imagines other goals for life, for love, for art, and for being" 4}

When thinking about the loss of The World we tried to save, I turn to J Halberstam's work linking failing to unexpected possibilities, and sees in failure ways of imagining, "not some fantasy of an elsewhere, but existing alternatives to hegemonic systems"(Halberstam 2011, p.89). In this rejection of the fantasy of an elsewhere, I read a rejection of the cruel optimism of a postrevolutionary-utopian-World-on-her-way. Instead, our attention turns to what already exists, growing in the fissures of white colonial heteropatriarchal capitalism. For those limited by Western notions of monorealism, this may involve learning to attend to other worlds already with us. The planning project has often flattened out worlds to make them externally knowable (Scott 1998), enabled by the ontology of a singular reality/World. This monorealism is, in Ghassan Hage's (2015, p.69) view, 'Western modernity's greatest 'achievement'...minimising our awareness of the multiplicity of realities in which we exist. But minimising is not obliterating." We failed to save The World, but there are other, subaltern worlds here, accessible if we attend and care for them.

Indeed, as we grapple with our own losses, we should listen to those walking with us who have already survived apocalypses. Claire G. Coleman (2017) argues that First Nations Australian Peoples are survivors of "end times" - that invasion represented an apocalypse. But First Nations Peoples are still here. Indigeneity still exists and is re/constituted, and modes of existence, being, and knowing may emerge from the practices of Indigenous Peoples where they are (Peters \& Andersen 2013), including in post-apocalyptic landscapes. Erica Violet Lee (2016, para36) writes of care for colonialism's wastelands and worlds beyond mere survival for Indigenous Peoples,

${ }^{4}($ Halberstam 2011, p.88). 
"even when we must piece those worlds together from gathered scraps, slowly building incandescent ceremonies out of nothing but our bodies, our words, and time."

For those feeling that we lost the fight to save The World this might be our apocalypse - but our loss, while devastating, is not unique. Us settlers should not be too self-centred in our failure. Others have lived through an apocalypse, or more than one; others lost the fight for their world/s (Danowski \& Viveiros de Castro 2017). They are still here: as Nayuka Gorrie said, "Colonisation was our apocalypse, and we are already living in a dystopian future, so we are ahead of the game" (Gorrie, in Yunkaporta 2017). Whilst non-Indigenous people should be careful not to appropriate or centre ourselves in the losses of First Nations Peoples, and be cautious of how we mourn that the same basic system of capitalism that produced colonialism is now destroying our World (after destroying the worlds of others for our benefit), we can listen. The generative, creative, evolving survival-and-beyond of First Nations Peoples in settler-colonial cities and countries tells us that while we might lose a world, other worlds are already here. The monorealism that dominates Western thought makes an apocalypse the apocalypse. Multirealism makes apocalypses possible, and while that is depressing in its own way, plurality means possibilities.

\section{For "still possible worlds"5}

I've attended four screenings of Fabrizio Terranova's film Donna Haraway: Story telling for eartbly survival. Each time I scribble notes in the dark, writing by feel alone. Reviewing the slightly damp pages, I always find the desperately scrawled words - 'for still possible worlds'. Haraway has a knack for phrases that etch themselves onto my bones: 'stay with the trouble'; 'we have a little time'; and 'still possible worlds'. The latter stays with me because it's an equivocal, realistic hope. It acknowledges that many worlds are closed to us, many futures are not in the becoming - too much damage has been done, too much lost, too many lifeways extinct or already living ghosts. For still possible worlds is not a hope that relies on grandiose, superhero feats of saving - there are

\footnotetext{
5 (Haraway in Terranova 2016)
} 
no heroic individuals or grand schemes or global total revolutions invoked. It is not teleological or Pollyannaish, nor does it deny the mourning of all we have lost and are yet to lose. We lost the war, and there is more loss to come. But. But. There are still possible worlds, still possible shared futures, still possible cities and some of them are worth having. These still possible worlds, the work of imagining them, prefiguring them, breathing and singing life into them, is the feminist urban praxis that feels available to me, and I offer it to my companions and comrades in political depression. There is something tender, care-full, about the possible worlds hummed by Haraway, and I turn to those Indigenous, queer, and/or feminist theorists writing about care and proximity in place, in conversation with the places and communities I think-with, to learn to attend and nurture tiny growing entanglements in wastespaces and ruins.

\section{"I am placed, I am located, therefore I am"6}

It feels a little redundant to argue for place in a geography journal. But in the spaces of left wing and environmental organising, place does need to be defended. Place is often not considered ontologically or epistemologically relevant, and may even be viewed as an impediment to revolutionary work. But 'Think Global, Act Local' ${ }^{7}$ as an environmentalist's imperative has failed us, fatally dividing thought from action (alongside capitalism's compression and attempted assassination of time/space). Schemes schemed from this dis/location, from Cartesian, binaristic thinking embedded in gendered and racialized oppression (Anderson 1997; Ahenakew 2016; Ahmed 2004 ) will fail to be emancipatory or transformative.

Place is not only something geographers can offer radical movements, place has something to offer the politically depressed. Feminisms for earthly survival, feminisms for still possible cities and for new modes of living and dying together in "capitalist ruins" (Tsing 2015) and postapocalyptic landscapes must be placed. Kombumerri philosopher Mary Graham (2017) said, "I am

\footnotetext{
6 (Graham 2018).

${ }^{7}$ In researching this paper I started typing the phrase into Google, and the second suggested autofill result (the first just completed the "think global act local" phrase) was "think global act local coca cola". This seems damning.
} 
placed, I am located, therefore I am”. From ontology to epistemology, Larsen and Johnson (2012, p.2) write that Indigenous intellectual praxis is formed from "concrete, place-based encounters and relationships...knowledge requires an actively inhabited place". This emplacement, this locating, is collective - places are always already inhabited. We are here, together. We think together from here. Thought is embedded "in the worlds one cares for" (Puig de la Bellacasa 2017, p.75). There is an uneasiness here for settler-colonial folk like myself - my being also comes from place, making my being indisputably constituted by colonialism. I live in Meanjin/Brisbane, land of the Jagera and Turrbal Peoples; in thinking-with this place, I must think-with how I come to be here and the responsibilities and obligations that creates.

Feminism for shared urban futures must attend to place, including the violence that co-produced these places and which perpetuates itself in how places are known, governed and planned. The compression of space-time, the acceleration of production, consumption, of daily practices (almost everything accelerated except the decomposition of the artefacts of our lives $)^{8}$, is one of the tools that has defeated us. Proximity, specificity, and particular entanglements, places and times matter (Van Dooren 2014; Haraway 2016; Todd 2017). What does it mean to think and do feminism with place? To dig our toes down into the humus and think-am ourselves from here, attuned to the ecological imperatives of our time-space location, dwelling in the otherness we already inhabit (Hage 2015, p.70), when we find ourselves politically depressed?

I find some guidance in Haraway - in the urban battlefield of our loss, in the rubble and debris, let us “join forces to reconstitute refuges” (Haraway 2016, p.192), and emphasise present practices of care and recuperation to keep still possible cities possible. In the remainder of this paper, I turn to

\footnotetext{
8 In fact, given the near permanence of many of these artefacts - including our toxic, plastic progeny, in Heather Davis' parlance, which are already "queering our bodies" (2015, p.237) - we may need to think of them, and "fossilbeings... as a kind of kin", to knit them into 'de-weaponised' relations and include them in our understandings of our responsibilities and obligations to places and each other (Todd 2017, p.107).
} 
the places and people I think-with, and the prefigurative practices of care and recuperation they are enacting.

\section{"All organizing is science fiction"9}

If we eschew futurism and insist on staying with the trouble, our "speculative fabulation[s]" (Haraway, 2016, p.122) might come from collective and care-full spaces of prefigurative community organising, in line with adrienne maree brown's (2017, p.197) claim that "all organising is science fiction". In my own experiences of political depression and ecological grief, still possible worlds can feel close in such spaces, and community organising projects like Brisbane Free University and Right to the City - BNE - prefigurative projects in a constellation of community organising projects in Meanjin/Brisbane - are examples of "sites of publicity and community formation" (Cvetkovich 2012, p.2). They are radical projects that centre a feminist ethic of care (Carlson \& Walker forthcoming) - care for organisers, participants, places - and rely heavily on joyful, relational organising.

Brisbane Free University (BFU) is a free education project emerging from Boundary Street in Meanjin/Brisbane (Carlson \& Walker forthcoming). BFU is committed to radical openness and a "fumble-friendly" approach to organising (Thompsett 2017, p.25); that is, at their core they refuse to commit to a pre-defined notion of success, and they explicitly leave room for failing. BFU embraces prefigurative politics: "a political orientation which, rather than aiming to overthrow or reclaim dominant structures, focuses energy on building alternatives in their interstices" (Thompsett 2016, p.63). The project currently comprises a radical reading group that meets weekly, a writing and collaborative 'undisciplined' research collective, and more public-facing events lectures/talks/panels held in public space, every 4-6 weeks. Beyond, across, and underneath these events and gatherings is a commitment not only to "emancipatory modes of 'study" (Thompsett 2017, p.26) but to the people and places engaged in and producing these radical pedagogies

\footnotetext{
${ }^{9}$ (maree brown 2017, p.197).
} 
(Carlson \& Walker forthcoming). Carlson and Walker situate BFU within a feminist ethics of care, arguing that care-full modes of study strive for "small and intimate ways to live and learn together", and in doing so:

"we find moments beyond the brutal carelessness of capitalism, small tastes of something better...As capitalist social reproduction falters and corresponding future imaginaries buckle under the weight of grief and precarity, we stop where and when we are, and turn towards each other" (Carlson \& Walker forthcoming, emphasis added).

In this radically open, prefigurative, fail friendly project, the collaborators centre care, affection, proximity, place, and encounter, and make small and tender offerings to the community they nurture in capitalist ruins.

One of the growing things nurtured by the care and the entwined intellectual work/political practices of BFU is Right to the City - BNE, a collective of folk living in Meanjin/Brisbane interested in radical spatial politics for just and sustainable cities. The group emerged out of an interest in 'the spatial turn', and the relationships between social and material conditions and urban space. Broadly opposed to neoliberal and capitalist modes of urban governance and production, the collective draws on a diverse (sometimes contradictory), shifting assemblage of theories, philosophies and practices in their organising, including right to the city theory, feminism, prefigurative politics, tactical urbanism, radical/insurgent planning, queer theory, urban ecology, queer ecology, decolonial theory, Marxism, anarchism, relational organising, electoral politics, and ethics of care. Right to the City - BNE is influenced by the idea that we can change the city to change ourselves, and change ourselves to change the city. In exercising a collective right to the city, we are not gaining influence over a city we have now (the city we lost), or the selves we have now, but something new and only partly imagined that emerges from generative, collective, creative appropriations and struggles. This is a kind of "mycelium magic" (maree brown 2017, p.20) - the idea that in working together through,across, and deep into place, our fruiting bodies 
will emerge in unpredictable, situated, and responsive formations, as we move toward just and sustainable cities, and "[create] conditions we have never experienced" (maree brown 2017, p.160) except in the ephemeral spaces prefigured through our actions.

When I ponder still possible cities and still possible futures from this dark place, and the work of reconstituting refuges and regenerating just, connected, and meaningful ways of living and dying together, I think of the gentle spaces of wonder these projects offer. These projects are radical but not revolutionary; they are not overly concerned with expansion or replication, and do not offer a recipe for defeating kyriarchal oppression with a single blow. I do not recount these projects as the sum total of politics worth doing; there are many dangers and limitations to everyday practices of care in proximity, not the least of which being that we are not all proximate to all in need of care, and that proximity is a product of political, socio-economic and historical relations that are not inherently good and which we might reproduce, when in fact some of them need determined unsettling. But, following Soren C. Larsen and Jay T. Johnson (2017) struggles together in place may offer something other than what we currently have, something worth having - place has agency that works on us, and we must attend to the development of cosmopolitical, pluralist, and educational (rather than essentialist) relationships to place. ${ }^{10}$ Everyday practices of emplaced care may be part of that practice of attentiveness for the politically depressed.

. I offer the examples herein as an indication of how those of us feeling the weight of political depression might craft a politics from dark places, and bear our grief and political depression “without paralysis" (Head 2016, p.7). These projects enact moments of counterhegemonic warmth, valuing smallness, proximity, relationships, connection, care, and affection, generally funnelled through collective appropriations of space. As they nestle into wasted urban spaces they do not only demonstrate that worlds worth having are still possible - they make tiny versions of

\footnotetext{
10 Of place, they write "it is also the scale of relationship, reciprocity, and respect across the manifold ontological styles of pluriverse...place provides the impetus for the protocols of pluralism” (Larsen and Johnson 2017, p.186).
} 
those worlds, spin them into being and breathe life into them for a time, and release them. The embodied gentleness of these projects, the permission wax and wane, the ephemerality of the work itself, and the emphasis on becoming rather than fixing, makes this form of organising and participation habitual - it makes an everyday practice out of care-full organising and spatial politics in which "we render each other capable" (Haraway 2016, p.136). This kind of care, this attentiveness to place and each other, and reconstituting refuges may be how those of us who feel helpless and hopeless can find a way to acting, to being, in the dark. - to stay with the trouble.

\section{“Just because there's no happy ending doesn't mean that we have to feel bad all the time"11}

It might be over, but this is not the end.

This politics of failure for the politically depressed is a commitment to still possible worldings that both "refus[es] to deny irreversible destruction, and refus[es] to disengage from living and dying well in presents and futures" (Haraway 2016, p.86), worldings operating in the space of everyday, ordinary life (Cvetkovich, 2012).In accepting our lost World and our failed revolution, we shed fixations on a clearly specified endpoint or pre-existing sets of strategies to get there, and instead focus on nurturing still possible cities in the cracks in the concrete, in the ruins and wastespaces we find ourselves in. These nurturing practices will be habitual, emphasising the daily and partial than the distant and complete, and resonate with Mary Graham's (1999, p.183) account of the custodial ethic in Aboriginal worldviews as "achieved through repetitive action, such that gradually, over time, the ethic becomes the 'norm."' In everyday habit the politically depressed might find room for small, tender, difficult things: care, affection, attentiveness to embodiment, place, encounter, situated entanglements, material effects, located practices.

11 “...or that feeling bad is a state that precludes feelings of hope and joy" (Cvetkovich 2012, p.206). 
In the examples of BFU and Right to the City - BNE we find practices of prefigurative urban organising that are consistent with grief, loss, and political depression in their everyday spatial politics for still possible cities. To the extent that these projects for still possible cities are engaged in imaginaries of the future, it is more in line with creating and enacting "a means not to an end, but only to future means" (Springer 2016, p.287). Though they may generate hope, these projects do not rely on it, committed as they are instead to "lived alternativity in the present" (Berlant 2011, p.75).

Making space for political depression and failure does not equate to nihilism, apathy, or resignation. Indeed, learning to feel our grief together and to work with political depression and failure may help enable the entangled, more-than-human communities of care that will make still possible cities worth having - and may, perhaps, lead us back to hope through practices, as Head (2016) suggests. In the words of Nēhiyaw philosopher Erica Violet Lee (2016, para35):

"To provide care in the wastelands is about gathering enough love to turn devastation into mourning and then, maybe, turn that mourning into hope."

But if not, well, you'll find me caring in and for wastelands anyway. What else am I going to do? 


\section{Acknowledgements}

My sincere love and thanks to all those I think-with who have been patient, kind and generous with me, and who to paraphrase Donna Haraway - render me capable, even in darkness. In particular: Anna Carlson, without whom I think very little; Shelley Cheng; Marissa Dooris; Liam Flenady, Amelia Hine; Declan McClure; Hannah ReardonSmith; Taylor Redwood; Jonathan Sri; Ollie; the generous regulars at the BFU Radical Reading Group; the brilliant co-producers at Radio Reversal; dear Right to the City-BNE conspirators; and Lachlan Griffin, my mentor in sunny cynicism and cheerful nihilism, who makes existential dread much less dreadful. My thanks also to Dallas Rogers, Libby Porter, Wendy Steele and the IAG Urban Geography Study Group for the invitation to do this work, all those who attended the presentation of this paper at the NZGS/IAG 2018 Conference and offered their thoughts, and Australian Geographer editors Chris Gibson and Natascha Klocker for their support and feedback. This paper was written with Maiwar at high tide, my bike and the orange ribbon we ride together at night, and the bush turkeys and curlews along the way. 


\section{References}

Ahenakew, C. (2016) 'Grafting Indigenous Ways of Knowing Onto Non-Indigenous Ways of Being The (Underestimated) Challenges of a Decolonial Imagination', International Review of Qualitative Research 9(3) pp.323-340.

Ahmed, S. (2004) The Cultural Politics of Emotion, Routledge, New York, USA.

Anderson, K. (1997) 'A walk on the wild side: a critical geography of domestication', Progress in Human Geography 21(4) pp.463-485.

Australian Law Reform Commission (2017) Pathways to Justice- An Inquiry into the Incarceration Rate of Aboriginal and Torres Strait Islander Peoples. Sydney, Australia.

Berlant, L. (2011) Cruel Optimism, Duke University Press, Durham, USA.

Berlant, L. (2012) 'Feel Tank', Counterpoints 367 pp.340-343.

Butler, J. (2004) Precarious Life: The Powers of Mourning and Violence, Verso, London, UK.

Butler, J. (2009) Frames of War: When is Life Grievable?, Verso, London, UK.

Carlson, A. and B. Walker (forthcoming). 'Free Universities and Radical Reading Groups: Learning to care in the here and now', Continumm.

Coleman, C. G. (2017) 'Apocalypses are more than the stuff of fiction - First Nations Australians survived one', available from: http://www.abc.net.au/news/2017-12-08/first-nationsaustralians-survived-an-apocalypse-says-author/9224026 (accessed 7 May 2018).

Cvetkovich, A. (2012) Depression: A Public Feeling, Duke University Press, Durham, USA.

Danowski, D., \& Viveiros de Castro, E. (2017) The Ends of the World (R. Nunes, trans. English edition), Polity Press, Cambridge, UK.

Davis, H. (2015) 'Toxic Progeny: The Plastisphere and Other Queer Futures', philoSOPHLA 5(2) pp. $231-250$.

Delegates at the Referendum Convention at Uluru. (2017) 'The Uluru Statement from the Heart', available from: https://www.1voiceuluru.org/the-statement/ (accessed 1 May 2018).

Gordon, A. F. (2004) Keeping Good Time: Reflections on Knowledge, Power, and People, Routledge, Oxon, UK. 
Gordon, S. (2017) 'Indigenous recognition: Turnbull Government's rejection of Uluru Statement from the heart indefensible', available from: http://www.abc.net.au/news/2017-10-

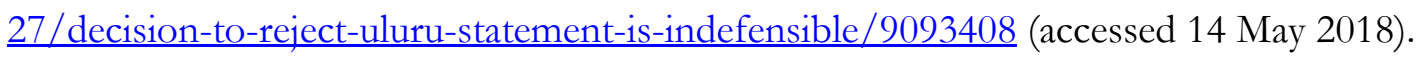

Graham, M. (1999) 'Some thoughts about the philosophical underpinnings of Aboriginal worldviews', Australian Humanities Review 45 pp.181-194.

Graham, M. (2018) 'Response to Tim Hollo's essay “The commons and the Commonwealth”, presentation at Commons/Wealth Games: The Commonwealth and the Commons, Griffith University, Brisbane, Australia.

Hage, G. (2015) Alter-politics: Critical Anthropology and the Radical Imagination, Melbourne University Press, Carlton, Australia.

Halberstam, J. (2011) The Queer Art of Failure, Duke University Press, Durham, USA.

Haraway, D. J. (2016) Staying with the Trouble: Making Kin in the Chtbulucene, Duke University Press, Durham, USA.

Head, L. (2016) Hope and grief in the Anthropocene: Re-conceptualising human-nature relations, Routledge, Oxfordshire, UK.

Holland, C. (2018) 'Close the Gap: A Ten-Year Review: the Closing the Gap Strategy and Recommendations for Reset', available from: https://www.humanrights.gov.au/sites/default/files/document/publication/CTG\%202018 FINAL-WEB.pdf (accessed 14 May 2018).

Know Your Meme (2017) 'The Darkest Timeline’, available from: http://knowyourmeme.com/memes/the-darkest-timeline (accessed 10 May 2018).

Larsen, S. C. and J. T. Johnson (2012) 'In between worlds: place, experience, and research in Indigenous geography', Journal of Cultural Geography 29(1) pp.1-13.

Larsen, S. C. and J. T. Johnson (2017) Being Together in Place: Indigenous Coexistence in a More Than Human World, University of Minnesota Press, Minneapolis, USA.

maree brown, a. (2017) Emergent Strategy: Shaping Change, Changing Worlds, AK Press, Chico, USA. Peters, E. and C. Andersen (2013) 'Introduction', in Peters, E. \& Andersen, C. (eds) Indigenous in the City: Contemporary Identities and Cultural Innovation, UBC Press, Vancouver, USA, pp.1-20. 
Puig de la Bellacasa, M. (2017) Matters of Care: Speculative Ethics in More Than Human Worlds, University of Minnesota Press, Minneapolis, USA.

Scott, J. C. (1998) Seeing Like A State: How Certain Schemes to Improve the Human Condition Have Failed, Yale University Press, New Haven, USA.

Springer, S. (2016) 'Fuck Neoliberalism', ACME: An International E-Journal for Critical Geographies 15(2) pp.285-292.

Stengers, I. (2015) In Catastrophic Times: Resisting the Coming Barbarism, Open Humanities Press, Lüneburg, Open Humanities Press, Germany.

Sultana, F. (2018) 'The false equivalence of academic freedom and free speech', $A C M E: A n$ International E-Journal for Critical Geographies 17(2) pp.228-257.

Terranova, F. (Director) (2016) Donna Haraway: Story telling for earthly survival [motion picture].

Thompsett, F. (2016) 'Learning by Doing by Learning: Reflections on scholar-activism with the Brisbane Free University', Australian Universities Review 58(2) pp. 59-66.

Thompsett, F. (2017) 'Pedagogies of resistance: Free universities and the radical re-imagination of study', Learning and Teaching 10(1) pp.24-41.

Todd, Z. (2017) 'Fish, Kin and Hope: Tending to Water Violations in amiskwaciwâskabikan and Treaty Six Territory', Afterall: A Journal of Art, Context and Enquiry 43 pp.102-107.

Tsing, A. L. (2015) The Mushroom at the End of the World: On the Possibility of Life in Capitalist Ruins, Princeton University Press, Princeton, USA.

Tsing, A., Swanson, H., Gan, E., \& Bubandt, N. (eds) (2017) Arts of Living on a Damaged Planet, University of Minnesota Press, Minneapolis, USA.

Van Dooren, T. (2014) Flight Ways: Life and Loss at the Edge of Extinction, Columbia University Press, New York, USA.

Violet Lee, E. (2016) 'In Defence of the Wastelands: A Survival Guide', Guts Magazine 7 (online).

Yunkaporta, T. (2017) 'I'm part of the world's oldest living culture, but could I kill a zombie with a boomerang?' available from: https://www.theguardian.com/artanddesign/2017/sep/27/im-part-of-the-worlds-oldestliving-culture-but-could-i-kill-a-zombie-with-a-boomerang (accessed 7 May 2018). 